\title{
Spatial Analysis of Rural-Urban Linkages in Basti District (U.P.)
}

\author{
Raisul Bari, Prof. Abdul Munir \\ Research Scholar Department of Geography, AMU Aligarh \\ Department of Geography, AMU Aligarh, 202002
}

\begin{abstract}
The rural urban interaction is an indispensable phenomenon. The linkages between the rural areas and the urban centers are complementary in nature. They are mutually benefited with each other. Thus, the rural-urban linkages may be defined as the two way movement of people, goods, capital, technologies and social transaction which is functional and structural.The present study is an attempt to understand the rural urban linkages in the Basti city. For this, primary data have been collected from the sampled villages of the district in order to understand the interaction and increasingly complex interrelations of the rural-urban areas. The study reveals that the rural areas are dependent upon urban centers, as $75 \%$ of the respondents visit to the city daily or weekly for marketing, education, jobs and health purposes that lead to social, economic and cultural transformation. Similarly, urban areas are benefited by the rural areas in a multiple ways; hence villagers send about $37.5 \%$ of their agricultural products (foodgrains $65 \%$, milk $20 \%$, vegetable $15 \%$ ) and other necessary food items to the city market. Furthermore, labour for industries and other allied activities are obtained from rural areas. It is found that quality of roads and distance of the villages from the city has a major impact on the rural-urban linkages.
\end{abstract}

Key words: rural-urban linkages, cultural transformation, indispensable phenomenon.

\section{Introduction}

The rural-urban linkages may be defined as the two way movement of people, goods, capital, technologies and social transaction which is functional and structural. Rural-urban linkages are both a cause and a consequence of socio-economic and cultural development. Town and cities function as service centers for their rural hinterlands, offering outlets for rural products public and commercial services, and employment opportunities; rural area provides raw and processed materials, labour and demand for urban goods and services. The nature and scope of rural-urban linkages is influenced by several factors, ranging from geographical and demographic characteristics (including the nature of agricultural field, population density and distribution patterns) to farming systems (based on land tenure and access to natural resources) to the availability of roads and transport networks linking local settlements to a number of urban centres where markets and services are located. With the decentralization, Local governments can play an important role in supporting positive ruralurban linkages. Transformations in the ways in which households and individuals make a living are perhaps the most striking aspect of rural-urban linkages and in many cases, involve multiple occupations ranging from farming to services to processing and manufacturing.

In economic terms, three types of rural-urban linkages are usually distinguished: consumption linkages (demand for final products), production linkages ('backward' or 'forward' supply of inputs among businesses), and financial linkages (e.g.' rents extracted by urban landholders, remittances by migrants, rural saving channeled through urban institutions). It is said that the flow of migrants from the countryside to towns is a major theme in rural-urban linkages. The subject has attracted a lot of attention of geographers, economists, regional planners and sociologists. No doubt vast volume of literature is available on the subject, but it is still required to study the nature and extent of rural-urban linkages of a particular region. The present study was undertaken with the aim in mind to identify the determinants and factors that can help in achieving socially and economically desirable linkages.

\section{Related Work}

Shah and Azam (1991) in their study in Sargodha district of Pakistan concluded that rural roads linked rural to urban and rural to rural with efficient mobility. Tacoli, (1998); Tacoli, (2003) Rosenthal,(2000) in their study have given the view that Rural-urban linkages are important for balance and sustainable rural development and urbanization. Strong linkages can improve the living conditions and employment opportunities of both rural and urban populations.

A more recent review (Lichter\& Brown, 2011) of the new "rural-urban interface" and the growing interpenetration of American urban and rural life points to the "enormous scale of rural-urban interdependence 
and boundary crossing, shifting- along many dimensions of community life - over the past decades" and twoway nature of these influences.

Sivkumaret al. (1999) in a study of growth linkage effects of agro industrialization in Dharmapuri district of Tamil Nadu found that nonfarm industries have caused rural to rural interaction and the export of value-added products from the area promoted rural-urban interaction and linkages.

Koppel et la. 1994; Unni 1996) in their work they found the process of diversification and the changing rural occupational structure in the developing countries that have created new opportunities leading to the emergence of a diversified occupational structure. These development forces through linkages effect have been able to attract or pull away rural labour from agriculture.

Evans (1990) in his study of structural transformation caused by rural urban linkage, described three phase of transformation.

Garrett (2005) worked out that strong links including the importance of rural demand on urban businesses and the significance of non-agricultural income in the form of remittances from seasonal and permanent migrants in rural households, with larger cities helped the villages successfully.

\section{Objectives}

The main objectives of this paper are as follows:

1. To study the nature and extent of rural-urban linkages in the Bastidistrict.

2. To identify the factors that affects the relationship between rural-urban linkages and level of socioeconomic development in the study area.

3. To evaluate the influence of the city on the sampled villages and to determine the magnitude of flow of agricultural products, and services.

\section{Study Area}

The study area is a district of Eastern Uttar Pradesh i.e. Basti which is located between $26^{\circ} 23^{\prime}$ and $27^{0}$ $30^{\prime}$ north latitude and $82^{\circ} 17^{\prime}$ and $83^{\circ} 20^{\prime}$ east longitude. The district lies entirely in the submontane plain. As of 2011 India census, Basti has a population of 24,61,056. Out of the total, 5.61 percent lives in urban areas of the district. The district has a population density of $916 \mathrm{~km}^{2}$. Basti district has been divided into 14 blocks and 3 tahsils. The Basti district is selected purposely for the study of rural-urban linkages for two reasons: their proximity to the base of researcher and the existence of varying degree of rural-urban linkages in the district. Total four villages were selected; 3 from Basti district and one from SantKabir Nagar, with consideration of distance and location. Out of four villages two villages i.e, Amauli and Karhi are 5km apart from the main city and are located at north-east and south-east of the city respectively. Rest of the two villages i.e. Sinhari and Paedi are located $12 \mathrm{~km}$ and $18 \mathrm{~km}$ from the city respectively. The villages,Karhi, and Sinharicome under Saughat block of Basti district and village Paedi comes under Semriyawan block of SantKabir Nagar. All the villages are along the main district road and are well connected with the city.

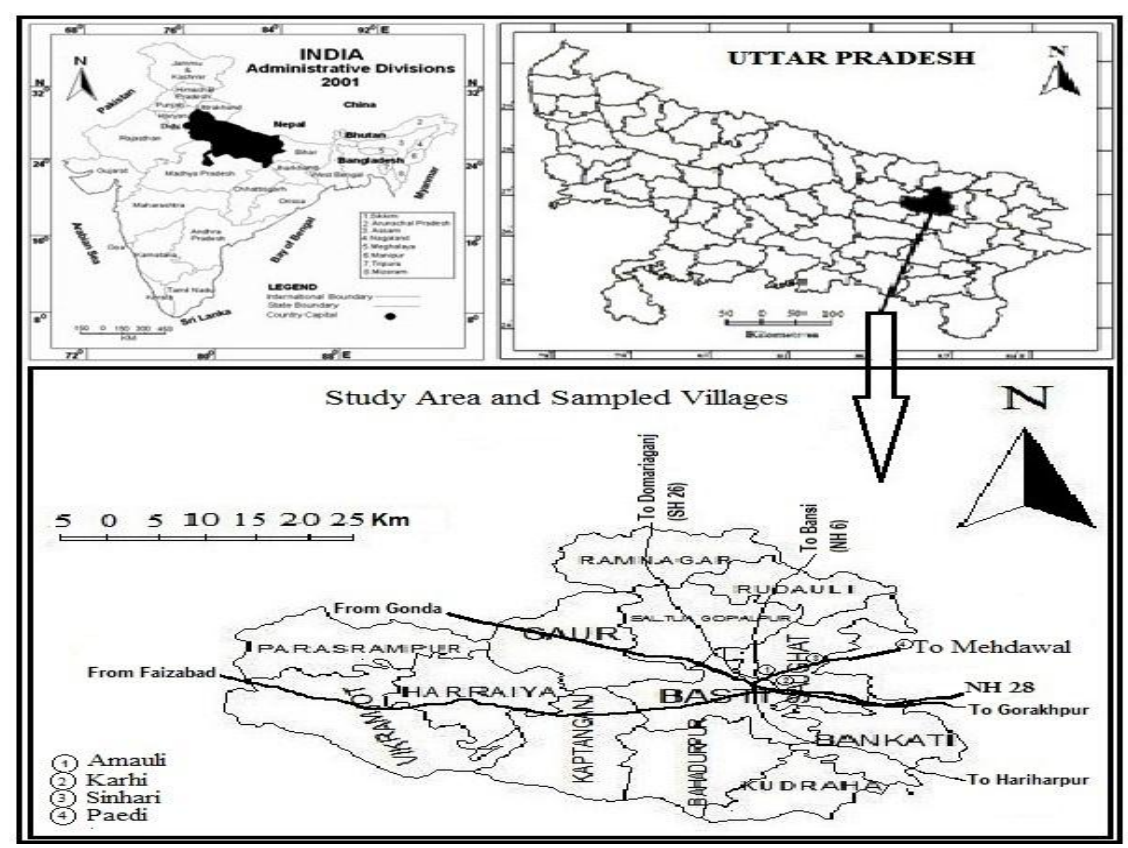

Fig. 1 Location Map of the Study Area 


\section{Methodology}

The present study is based on primary data conducted through a well structured questionnaire. The data has been collected from four villages of the Basti district through stratified purposive sampling technique. The sampling technique was applied for the face to face interviews of the local respondents to obtain data and to measure respondents' attitude about agriculture, market, services and other related aspect that links the city with the rural areas. Other statistical and GIS techniques were also used. The primary data were processed on computer using the excel software and MS words.

\section{General profile of the sampled villages}

Before evaluating the rural-urban linkages in the Basti district, it is necessary to know the general profile of the sampled villages. Some of the selected variables for the study are, distance from the city in $\mathrm{km}$, transportation and communication, number of schools, banking facilities. All the sampled villages have primary schools but they do not have even one secondary or higher secondary school. To avail the banking facilities the villagers have to travel $5-10 \mathrm{~km}$ distance. If we see the quality of roads and connectivity all villages are connected with metalled roads, but unlike Karhi these roads are not in good condition. In Paedi village large proportion of the roads is semi-metalled, but the village is connectedwith the city bymetalled road. All the villages have electricity facilities but they get the service on an average for 8-10 hours per day. Amauli is an exception and gets electricity for more than 15 hour a day because it is being provided electricity by the electric service of the city. There are no public health care facilities in these villages. Almost all the villages have telephone connection by landline or mobile phone.

Health care facilities are mainly provided by private clinicsrun by less qualified and inexperienced doctors and even there is not a single primary health care centre which is run by the Government. Women and Child health care units are also lacking in these sampled villages. So, most of the people go to the city for the health care and medical facilities.

Socio-economic and cultural status of the respondents

Socio-cultural status: The data which has been collected from the respondents show that $60 \%$ of the respondents were from Hindu community and 40\% were from Muslim community. Out of 40 respondents, 18 were qualified only up to primary school level, 11 were senior secondary school level, 8 respondents were graduates and the rest were post graduates (Table 1).

Economic Status: Among the 40 respondents, 30\% were engaged in government services, 25\% were engaged in agricultural sector, $17.5 \%$ respondents earn their livelihood as daily labourers and 11 were shop keepers (Fig. 3).Nearly $40 \%$ of the respondents who were engaged in agriculture were earning less than 5 thousand rupees; it was only because of the low agricultural yield. About 30\% were earning 5-10 thousands, $12 \%$ of the respondents were earning 10-15 thousands and $17.5 \%$ were earning more than 15 thousands per month. Only $15 \%$ of the respondents were living in kacha or semi kacha houses and $85 \%$ were residing in pucca houses.

Table 1: Socio Economic and Cultural Status of Respondents in Sampled Villages (2013)

\begin{tabular}{|c|c|c|c|c|c|c|c|c|}
\hline \multirow{2}{*}{ Village } & \multicolumn{2}{|c|}{ Religion of the Respondents } & \multicolumn{3}{|c|}{ Caste } & \multicolumn{3}{|c|}{ Housing Status } \\
\hline & Hindu & Muslim & General & OBC & SCs/STs & Kachha & & Pucca \\
\hline Amauli & 30 & 70 & 20 & 70 & 10 & 10 & & 90 \\
\hline Karhi & 100 & 0 & 10 & 90 & 0 & 0 & & 100 \\
\hline Sinhari & 100 & 0 & 40 & 50 & 10 & 40 & & 60 \\
\hline Paedi & 10 & 90 & 70 & 30 & 0 & 10 & & 90 \\
\hline Total & 60 & 40 & 35 & 60 & 5 & 15 & & 85 \\
\hline \multirow{2}{*}{ Village } & \multicolumn{5}{|c|}{ Educational Status of Respondents } & \multicolumn{3}{|c|}{ Marital Status } \\
\hline & Primary & Sec. School & Graduate & \multicolumn{2}{|c|}{ Post Graduate } & Married & \multicolumn{2}{|c|}{ Unmarried } \\
\hline Amauli & 70 & 10 & 10 & \multicolumn{2}{|r|}{10} & 90 & \multicolumn{2}{|c|}{10} \\
\hline Karhi & 30 & 30 & 20 & \multicolumn{2}{|r|}{20} & 100 & \multicolumn{2}{|r|}{0} \\
\hline Sinhari & 40 & 40 & 20 & \multicolumn{2}{|r|}{0} & 100 & \multicolumn{2}{|r|}{0} \\
\hline Paedi & 40 & 30 & 30 & \multicolumn{2}{|r|}{0} & 100 & \multicolumn{2}{|r|}{0} \\
\hline Total & 45 & 27.5 & 20 & \multicolumn{2}{|r|}{7.5} & 97.5 & \multicolumn{2}{|r|}{2.5} \\
\hline \multirow[b]{2}{*}{ Village } & \multicolumn{3}{|c|}{ Occupational Structure of the Respondents } & \multicolumn{5}{|c|}{ Income of Respondents } \\
\hline & Govt. Service & Agriculture & Labour & Shop & $<5000$ & $\begin{array}{l}5000- \\
10000\end{array}$ & $\begin{array}{c}10000- \\
15000\end{array}$ & $15000>$ \\
\hline Amauli & 20 & 10 & 20 & 50 & 30 & 50 & 20 & 0 \\
\hline Karhi & 50 & 20 & 30 & 0 & 30 & 10 & 30 & 30 \\
\hline Sinhari & 30 & 20 & 10 & 40 & 50 & 20 & 0 & 30 \\
\hline Paedi & 20 & 50 & 10 & 20 & 50 & 40 & 0 & 10 \\
\hline Total & 30 & 25 & 17.5 & 27.5 & 40 & 30 & 12.5 & 17.5 \\
\hline
\end{tabular}


Source: Field Survey Conducted in August, 2013

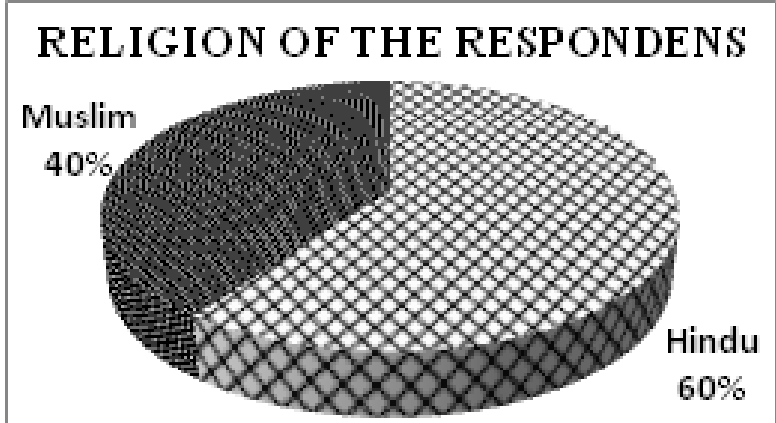

Fig. 2

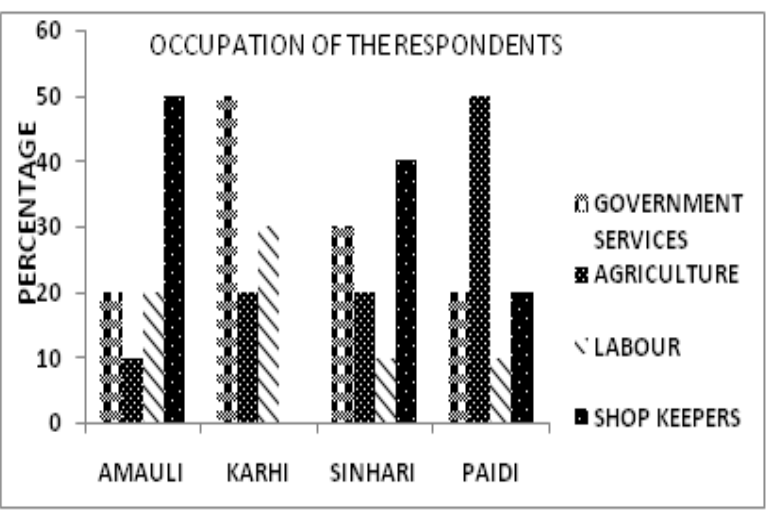

Fig. 3

Linkages of the villages with the city

The agricultural activities directly or indirectly link rural areas with the city. As we know that agriculture is the backbone of the rural economy, nearly $90 \%$ of the people are engaged in agricultural activities. Table 2 shows that out of 40 respondents, 28 grow cereal crops in their field and 8 of them grow vegetables. Villages situated near to the city produce vegetables because of the easy transport linkages with urban markets. Very few people grow fodder for their cattle, other farming activities were negligible, while pisiculture was reported in Paedi village.

Nearly 50\% respondents said that they have agricultural equipments like tractors, threshers, fodder cutters, pumping set etc. It is evident from the table that villages growing cereal crops have more agricultural equipments. In livestock rearing buffalo, cow and goat are reared by $60 \%$ of the people in these sampled villages. Buffalos and cows are the main source of the milk in the villages. Milk is the important item sent to the city market by the villagers and contributes about $20 \%$ of total sent items. More than $62 \%$ of the total milk is sent by Amauli and Karhi. All the villages are somehow linked with the city as they supply the agricultural products like milk, vegetables, and food grains (Fig. 5).

From Table 2 it is evident that Amauli village sells $70 \%$ of agricultural products to the city market, while in contrary of this the village Paedi sell $90 \%$ of its agricultural products in the local market which clearly indicates that the best quality of roads and distance have a major impact on the rural-urban linkages. On the other hand the purchasing of agricultural inputs by the Amauli and Karhi village are mainly from the city because of the proximity of the city. While Sinhari and Paedi draw most of their agricultural inputs like seeds, fertilizers, insecticides, pesticides etc from the local market because these villages are far away from the city and they went to the city only for heavy agricultural inputs like tractor, thrasher, and pumping sets. The agricultural sector needs well functioning local as well as urban markets to drive growth, employment and economic prosperity in rural areas. The link of the city with the sampled villages has modified the attitude of the farmers and also changed the cropping pattern. The interaction between the rural and urban areas through transportation helps the farmer to know the real market price of agricultural products that leads to the improvements in the fields and life of the farmers. All the above mentioned facts show that rural-urban linkages have not only benefitted the rural areas but also benefitted the city by providing agricultural products.

Table 2: Agriculture and Rural-Urban Linkages of Respondents in Sampled Villages

\begin{tabular}{|c|c|c|c|c|c|c|c|c|c|c|}
\hline \multirow[b]{2}{*}{ Village } & \multicolumn{6}{|c|}{ Agricultural Equipments } & \multicolumn{4}{|c|}{ Livestock } \\
\hline & Tractor & Thresher & $\begin{array}{c}\text { Fodder } \\
\text { cutter }\end{array}$ & \multicolumn{2}{|c|}{ Pumping set } & Tube well & \multirow{2}{*}{$\frac{\text { Buffalo }}{2}$} & Cow & Goat & Others \\
\hline Amauli & 1 & 1 & 3 & \multicolumn{2}{|c|}{1} & 0 & & 2 & 3 & 0 \\
\hline Sinhari & 1 & 1 & 1 & \multicolumn{2}{|c|}{4} & 0 & 2 & 3 & 0 & 0 \\
\hline Paedi & 3 & 2 & 2 & \multicolumn{2}{|c|}{5} & 0 & 3 & 3 & 1 & 0 \\
\hline Village & $\begin{array}{c}\text { Veget } \\
\text { able }\end{array}$ & Fruits & Crops & Fodder & Fish & Others & $\begin{array}{c}\text { Local } \\
\text { market }\end{array}$ & City & & $\begin{array}{c}\text { Other } \\
\text { urban } \\
\text { Centers }\end{array}$ \\
\hline Amauli & 30 & 0 & 60 & 10 & 0 & 0 & 30 & 70 & & 0 \\
\hline Karhi & 20 & 0 & 80 & 0 & 0 & 0 & 60 & 40 & & 0 \\
\hline
\end{tabular}


Spatial Analysis Of Rural-Urban Linkages In Basti District (U.P.)

\begin{tabular}{|c|c|c|c|c|c|c|c|c|}
\hline Total & 20 & 0 & & 2.5 & & 62.5 & 37.5 & 0 \\
\hline \multirow[b]{2}{*}{ Village } & \multicolumn{4}{|c|}{ Most Supplied items to the City } & \multicolumn{4}{|c|}{ Markets for Agricultural Inputs } \\
\hline & Vegetable & Food grain & Milk & Fruits & City & Town & & Local market \\
\hline Amauli & 10 & 60 & 30 & 0 & 60 & 0 & & 40 \\
\hline Karhi & 20 & 60 & 20 & 0 & 60 & 0 & & 40 \\
\hline Sinhari & 20 & 60 & 20 & 0 & 30 & 0 & & 70 \\
\hline Paedi & 10 & 80 & 10 & 0 & 20 & 10 & & 70 \\
\hline Total & 15 & 65 & 20 & 0 & 42.5 & 2.5 & & 55 \\
\hline
\end{tabular}

Source: Field Survey conducted in August, 2013

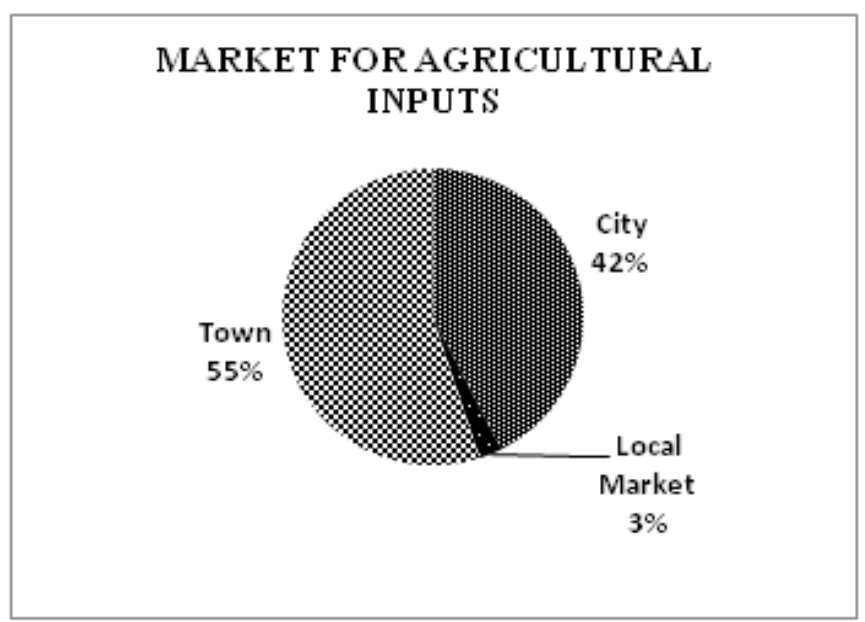

Fig. 4

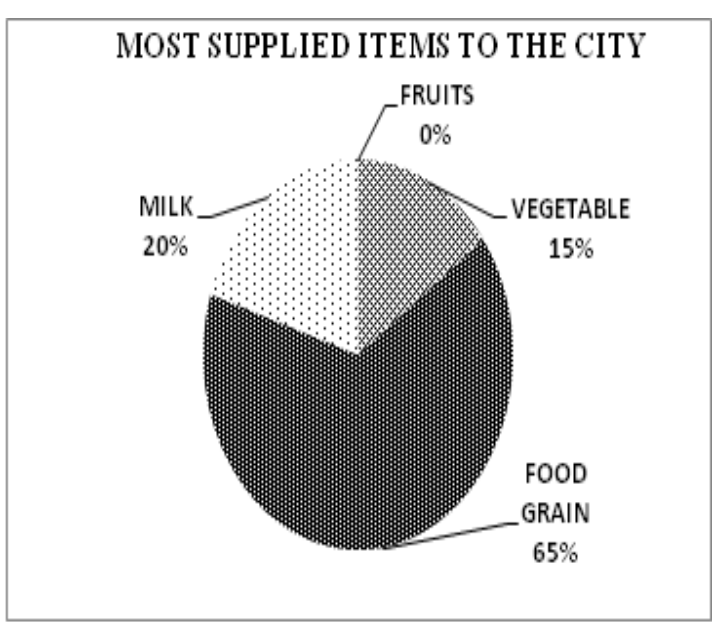

Fig. 5

Education and rural-urban linkages

If we see the influence of the city on these villages in the field of education $40 \%$ respondents prefer to send their children to the city while $60 \%$ children are getting education in their respective villages. Most of the children that go to the city for education are mainly from Karhi and Sinhari. In Amauli which is economically backward village, $82 \%$ children get education in local schools (Fig. 7). Better road connectivity encourages rural students irrespective of boy and girl to gain higher education in nearby towns. Distance of school from the sampled villages has affected the villagers to not send their children to the city due to the bad transportation that linked the city to remote villages. The village (, Karhi) near to the city prefer to send their children to school by cycle. But the villages (Sinhari, Paedi) which are far away from the city use school van as a mode of transportation for the school children. It is shown in Table 3. Schools in the city provided the better educational facilities as compared to schools of the local villages. It is found in the study that the people who are economically good generally send their children to the city for schooling.

Table 3: Services provided by the City

\begin{tabular}{|c|c|c|c|c|c|c|c|c|}
\hline \multirow[b]{2}{*}{ Village } & \multicolumn{4}{|c|}{ Frequency of City Visit by Respondents } & \multicolumn{4}{|c|}{ Purpose of Travel to the City } \\
\hline & 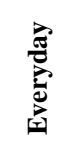 & $\frac{\vec{x}}{\frac{\pi}{0}}$ & 冚 & 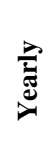 & 氕 & 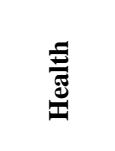 & $\frac{0}{0}$ & 电紫 \\
\hline Amauli & 30 & 30 & 30 & 10 & 20 & 20 & 0 & 60 \\
\hline Karhi & 70 & 20 & 10 & 0 & 10 & 10 & 20 & 60 \\
\hline Sinhari & 40 & 40 & 20 & 0 & 0 & 20 & 30 & 50 \\
\hline Paedi & 10 & 60 & 30 & 0 & 10 & 40 & 0 & 50 \\
\hline Total & 37.5 & 37.5 & 22.5 & 2.5 & 10 & 22.5 & 12.5 & 55 \\
\hline \multirow{2}{*}{ Village } & \multicolumn{4}{|c|}{ Child Getting Education in the City } & \multicolumn{4}{|c|}{ Distance of School from the Village in $(\mathrm{km})$} \\
\hline & \multicolumn{2}{|c|}{ Yes } & \multicolumn{2}{|c|}{ No } & $<5 \mathbf{~ k m}$ & $5-10 \mathrm{~km}$ & $\begin{array}{c}10-15 \\
\text { km }\end{array}$ & $>15 \mathrm{~km}$ \\
\hline Amauli & \multicolumn{2}{|c|}{30} & \multicolumn{2}{|c|}{70} & 2 & 1 & 0 & 0 \\
\hline Karhi & \multicolumn{2}{|c|}{60} & \multicolumn{2}{|c|}{40} & 2 & 4 & 0 & 0 \\
\hline Sinhari & \multicolumn{2}{|c|}{40} & \multicolumn{2}{|c|}{60} & 0 & 0 & 4 & 0 \\
\hline Paedi & \multicolumn{2}{|c|}{30} & \multicolumn{2}{|c|}{70} & 0 & 0 & 0 & 3 \\
\hline Total & \multicolumn{2}{|c|}{40} & \multicolumn{2}{|c|}{60} & 4 & 5 & 4 & 3 \\
\hline
\end{tabular}


Spatial Analysis Of Rural-Urban Linkages In Basti District (U.P.)

\begin{tabular}{|l|c|c|c|c|}
\hline \multirow{2}{*}{ Village } & \multicolumn{3}{|c|}{ Mode of Transportation of School Children } \\
\cline { 2 - 5 } & Cycle & Motor Cycle & \multicolumn{2}{c|}{ School Van } \\
\hline Amauli & 3 & 0 & 0 & 2 \\
\hline Karhi & 3 & 1 & 0 & 3 \\
\hline Sinhari & 1 & 0 & 0 \\
\hline Paedi & 0 & 2 & 0 \\
\hline Total & 7 & 3 & 0 \\
\hline
\end{tabular}

Source: Field Survey Conducted in August, 2013

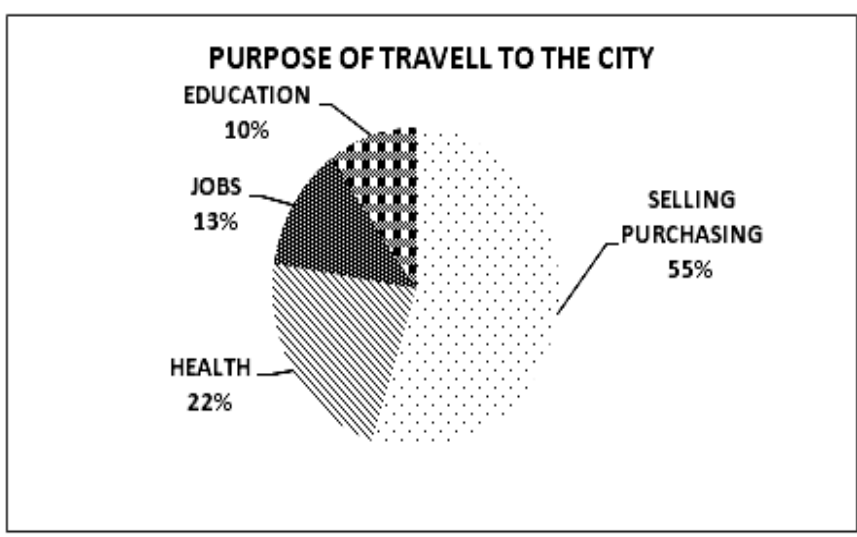

Fig. 6

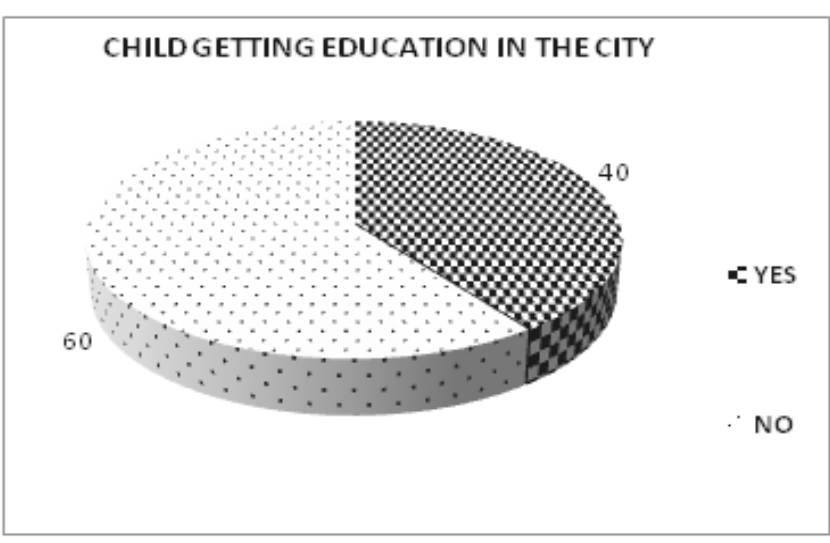

Fig. 7

\section{City's link with the sampled villages}

City is the main source of all services provided to the neighbouring villages. People of the village go to the city for various types of services. It is evident from the Table 3, that $37.5 \%$ respondents of these sampled villages go to the city everyday for many purposes like education, health, selling, purchasing, and jobs. while $37.5 \%$ goes weekly and nearly $22 \%$ go once in a month. The frequent or daily visit of the people to the city is mainly for selling and purchasing, job and education purposes while $22 \%$ people go to the city weekly or monthly for health purpose (Fig. 6).

Selling, purchasing and health care show the strong link of the city to the villages. People of the sampled villages (Sinhari and Paedi) go to the city only when they have to purchase costly and rare articles for the marriages and other ceremonies.

\section{Response of the respondents regarding the services and impact of the city on the sampled villages}

As for as satisfaction regarding the services of the city is concerned, 65\% people are satisfied, with people of the Karhi and Paedi showing maximum satisfaction. About 34\% people are not satisfied with the services of the city. But when we compare the services provided by the city market and local market of the villages, then $67.5 \%$ people show the maximum satisfaction from village market and only $32.5 \%$ people considered that city market provide better facilities than the local market (Fig. 8). As most of the people are satisfied with the service of the city but they can not avail the facilities of the city because of the bad quality of road, market price and insecurity in the city. About $60 \%$ of the villagers face various types of difficulties during their visit to the city that have negative impact on the rural- urban relationship. The interactions between the city and sampled villages have great impact on the life-style of the commuters and villagers. About 55\% of the respondents have said that their life-style is influenced by the city's life-style and $45 \%$ of the respondents are of the view that their life-style is not affected by the city's life style(Table 4).

As we know that every city somehow influences the socio-economic condition of the surrounding villages. In the study it is found that $75 \%$ respondents acknowledge the impact of the city on the socio-economic condition of the sampled villages. It is only because of easier access to facilities such as social infrastructure like banks, currier, hospitals, and agricultural inputs through MandiSamiti, IFFCO agricultural centre and other important kisan help centers in the city. The village Karhi is economically advanced as compared to other three sampled villages because of better connectivity and access to the city market. 
Table 4: Response of the Respondents regarding services provided by the City (in \%)

\begin{tabular}{|c|c|c|c|c|c|c|}
\hline \multirow[t]{2}{*}{ Village } & \multicolumn{2}{|c|}{$\begin{array}{c}\text { Satisfied with } \\
\text { Services of the City }\end{array}$} & \multicolumn{4}{|c|}{$\begin{array}{l}\text { Market of the City Provides Better Facilities } \\
\text { than the Local Market }\end{array}$} \\
\hline & Yes & No & \multicolumn{2}{|c|}{ Yes } & \multicolumn{2}{|c|}{ No } \\
\hline Amauli & 60 & 40 & \multicolumn{2}{|c|}{60} & \multicolumn{2}{|c|}{40} \\
\hline Karhi & 70 & 30 & \multicolumn{2}{|c|}{80} & \multicolumn{2}{|c|}{20} \\
\hline Sinhari & 60 & 40 & \multicolumn{2}{|c|}{80} & \multicolumn{2}{|c|}{20} \\
\hline Paedi & 70 & 30 & \multicolumn{2}{|c|}{50} & \multicolumn{2}{|c|}{50} \\
\hline Total & 65 & 35 & & & & \\
\hline \multirow[t]{2}{*}{ Village } & \multicolumn{2}{|c|}{$\begin{array}{l}\text { Difficulties faced } \\
\text { in the city }\end{array}$} & \multicolumn{2}{|c|}{$\begin{array}{l}\text { Impact of city's life style on the } \\
\text { commuters and villagers }\end{array}$} & \multicolumn{2}{|c|}{$\begin{array}{l}\text { Impact of the city on the socio- } \\
\text { economic conditions of commuters } \\
\text { and villagers }\end{array}$} \\
\hline & Yes & No & Yes & No & Yes & No \\
\hline Amauli & 60 & 40 & 50 & 50 & 70 & 30 \\
\hline Karhi & 70 & 30 & 60 & 40 & 70 & 30 \\
\hline Sinhari & 50 & 50 & 60 & 40 & 90 & 10 \\
\hline Paedi & 60 & 40 & 50 & 50 & 70 & 30 \\
\hline Total & 60 & 40 & 55 & 45 & 75 & 25 \\
\hline
\end{tabular}

Source: Field Survey Conducted in August, 2013

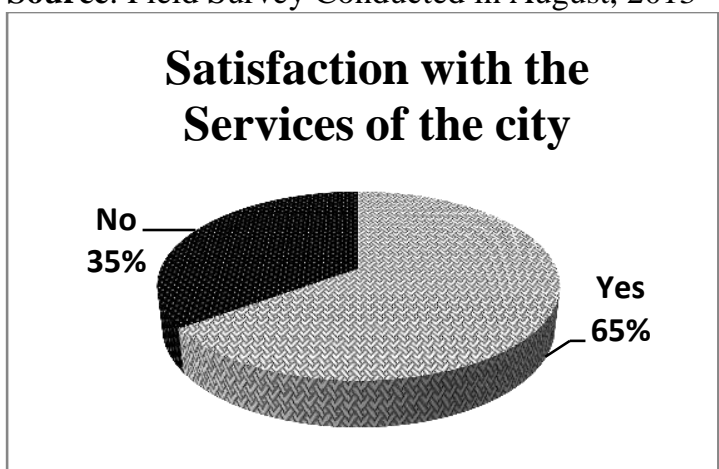

Fig. 8

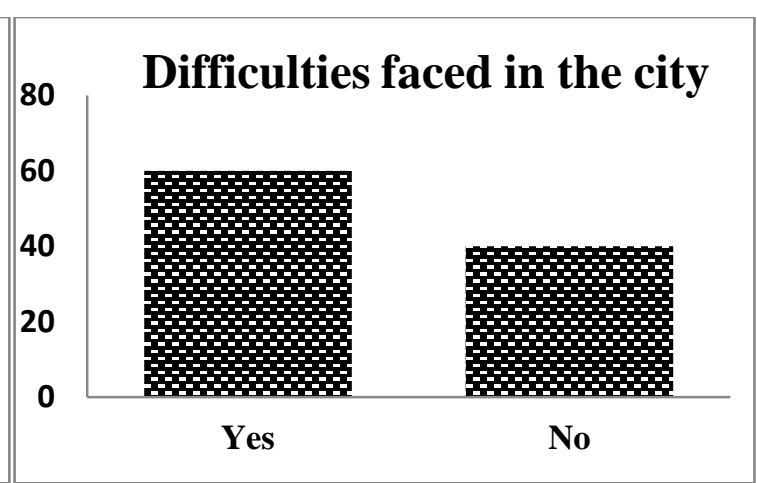

Fig. 9

\section{Conclusion}

To remove the urban rural imbalance and achieve faster development in countryside as well as in urban areas, governments at the national and local level must recognize the growing importance of the urban-rural linkages and craft policies that make adequate investments in infrastructure, particularly transportation, to improve rural agricultural condition while allowing access to markets. There should be provision for providing loan and agricultural subsidies to the villagers. Urban market is key in rural-urban linkage, it must be properly regulated and intermediaries should be totally removed. If various agricultural subsidies are given to the rural farmer, it can be instrumental in rural as well as urban development. Rural road systems that link the immediate urban areas have been acknowledged that these roads have improved social, physical, financial and human capital of the population of the connected villages. All the villages should have proper road network that connects with the city. The question have been raised on the security of the visitors in the city like extortion of money from vendors by the local and the city police, such type of activities should be strictly controlled, because it becomes a major hurdle in rural-urban linkages and retrogresses rural as well as urban development.

\section{Reference}

[1]. Alexander, K.C. (1985) “Agricultural Development and Social Transformation," Journal of Rural Development, Vol. IV, (5), p. 65.

[2]. Dabson, B. et al. (2012)Case Studies of Wealth Creation and Rural-Urban ConnectionsColumbia, pp.15-16.

[3]. Dastagiri, M.B. (1999) "Rural-Urban Linkages through Agricultural and Non-Agricultural Investment in India",Indian Journal of Agricultural Economics, 54 (3), p. 433.

[4]. Evans, H. E. (1990) Rural-urban linkages and structural transformation, Report INU 71, Infrastructure and Urban Development Department, The World Bank, Washington DC; UNDP/UNCHS (Habitat) (1995) Rural-Urban Linkages: Policy Guidelines for Rural Development, Paper prepared for the Twenty-Third Meeting of the ACC Sub-Committee on Rural Development, UNESCO Headquarters, Paris, 31 May - 2 June 1995.

[5]. Jagannathan, N.V.; Halder, A. (1988) "A Case Study of Pavement Dwellers in Calcutta: Occupation, Mobility and Rural-Urban Linkages", Economic and Political Weekly, Vol. XXIII, No. 49, pp. 2602-2605.

[6]. Koppel, B.et al., ed. (1994) Development or Deterioration: Work in Rural Asia,Boulder: Lynne Rienner Publishers.

[7]. Shah, Q. A. and Azam, M. (1991) "Impact of Rural Roads on Employment: A Case of District Sargodha",Journal of Rural Development andAdministration, 23 (4), pp.87-103.

[8]. Siddhartha, K. and Mukherjee, S. (2004) "Cities Urbanisation and Urban Systems", Kisalaya Publications Pvt. Ltd., Allahabad, pp.113-136.

[9]. Sivkumar, S.D., Balasubramaniam, R. and Srinivasan, N. (1999) “Growth Linkage Effects of Agro-Industrialisation”,Indian Journal of Agricultural Economics, 54 (3), p. 418.

[10]. Tacoli, C. (1998) "Rural-urban interaction: A guide to the literature",Environment and Urbanisation,Vol. X (1) pp.147-66. 